\title{
Z-GP Modification to CI-994, a Histone Deacetylase Inhibitor and the Application in Targeting Carcinoma Chemotherapy
}

\section{Yuanyuan Deng ${ }^{1}$, Peipei $\mathrm{Gao}^{2}$, Cuiping Guo ${ }^{2}$, Long $\mathrm{Wu}^{1}$, Jun $\mathrm{Xu}^{4}$, Heru Chen ${ }^{2,3}$ and Shao-hui Cai ${ }^{1 *}$}

${ }^{1}$ Department of Clinical Pharmacology, College of Pharmacy, Jinan University, Guangzhou 510632, P. R. China

${ }^{2}$ Institute of Traditional Chinese Medicine and Natural Products, College of Pharmacy, Jinan University, Guangzhou 510632, P. R. China

${ }^{3}$ Guangdong Province Key Laboratory of Pharmacodynamic Constituents of TCM and New Drugs Research, Guangzhou 510632, P. R. China

${ }^{4}$ College of Medicine, Jinan University, Guangzhou 510632, P. R. China

\begin{abstract}
An adduct, namely (S)-4-acetamido- $N$-(2-( $N$-benzyloxycarbonyl- glycylprolyl)aminophenyl)benzamide (Z-GP$\mathrm{Cl}-994)$ has been designed and synthesized. All the evidences disclose that Z-GP-Cl-994 is not the substrate of fibroblast activation protein- $\alpha(F A P \alpha)$. However, the adduct is the substrate of another unknown enzyme which is ubiquitous in tumor tissue. The cytotoxicity of the adduct against HepG2, A549 and NIH3T3 cell lines is apparently decreased when compared to that of the parent compound (Cl-994). Additionally, the inhibition rate of Z-GP-Cl-994 on histone deacetylase is significantly lower than that of $\mathrm{Cl}-994$. All the results suggest preliminarily that Z-GP-Cl-994 is promising to achieve enzyme-targeting delivery and to reduce systemic toxicity.
\end{abstract}

Keywords: Prodrug; HDAC inhibitor; Chemotherapy; FAPa

\section{Introduction}

Chemotherapy for the treatment of cancer was introduced into the clinic more than sixty years ago. Although this form of therapy has been successful for the treatment of some tumors such as testicular cancer and certain leukemias, however, the success suffers from systemic toxicity due to a lack of specificity, rapid drug metabolism, and both intrinsic and acquired drug resistance [1,2]. One effective strategy to solve (or partially solve) this problem is to make chemotherapeutic drugs specifically target only neoplastic cells in order to decrease tumor burden by inducing cytotoxic and/or cytostatic effects with minimal "collateral damage" to normal cells. So far, there are a number of anticancer prodrugs have been reported [2-4]. Ideally, the design of anticancer prodrugs should be selectively activated by some specific enzymes or metabolic pathways which are (is) only present or predominantly present in targeted tumor site [5-7].

Recently, we are concerning about the application of fibroblast activation protein- $\alpha(\mathrm{FAP} \alpha)$ [8-10] as a targeting enzyme in prodrug design. Investigations have disclosed that FAPa is highly restricted to tumor-associated fibroblast (TAF) in over $90 \%$ of common human epithelial carcinomas, but is not detected in normal adult tissues except tissues of healing wound [10-13]. This enzyme is a type II transmembrane serine protease belonging to the post prolyl peptidase family with essential functions to regulate the growth and development of tumor [12,13]. Compared with dipeptidyl peptidase IV (DPPIV), which is one of its homologous family members, FAP $\alpha$ exclusively exhibits endopeptidase activity toward $\mathrm{N}$-blocked peptide substrates [14]. And more specifically, Aertgeets et al. substantiated that FAPa, but not DPPIV, could hydrolyze the $N$-terminal benzyloxycarbonyl (Cbz) blocked peptides, such as Z-GP-AMC [15]. Considering the highly selective expression and the unique proteolytic activity of FAPa in tumor tissue, Huang et al. constructed a Z-GP-doxorubicin adducts (Z-GP-Dox) and proved the desired targeting effect in $4 \mathrm{~T} 1$ tumorbearing model [16]. However, whether if FAP- $\alpha$ is able to hydrolyze universally any Z-GP adducts remains unknown.

CI-994, also named Tacedinaline (Figure 1), is a potent member of the benamide class of histone deacetylase (HDAC) inhibitors which demonstrates significant anticancer activity against a broad spectrum of murine, rat and human tumor models [17-19]. Currently this compound is progressing through clinical trials in combination with other standard anticancer agents such as carboplatin, paclitaxel [20], capecitabine [21] or gemcitabine [22]. But it induces adverse effects including thrombocytopenia, anemia and neutropenia [23]. Therefore, we are quite interested in applying the above-mentioned strategy, that is, the Z-GP modification to CI-994 to construct Z-GP-CI-994 adduct (Figure 1), in the purpose of decreasing these side effects.

\section{Experimental}

\section{Materials and procedures}

Chemicals and materials: $p$-Aminobenzoic acid and benzene1,2-diamine were purchased from Shanghai Jingchun Ltd., China; $\mathrm{N}$-benzyloxycarbonylglycylproline (Z-GP-OH) was from GL Biochem (Shanghai) Ltd (China); Silica gel for column chromatography was purchased from Qingdao Marine Chemicals Inc(China); Epigenase HDAC activity/inhibition direct assay kit was from Epigentek Group Inc (USA). 3-(4,5-Dimethylthiazol-2-yl)-2,5-diphenyl tetrazolium bromide (MTT) and DMSO were purchased from Sigma; Recombinant human FAPa (rhFAPa) was purchased from R\&D Systems (USA). The buffers used were vacuum-filtered through $0.2-\mu \mathrm{m}$ membrane. Cell culture media, supplements and fetal bovine serum (FBS) were

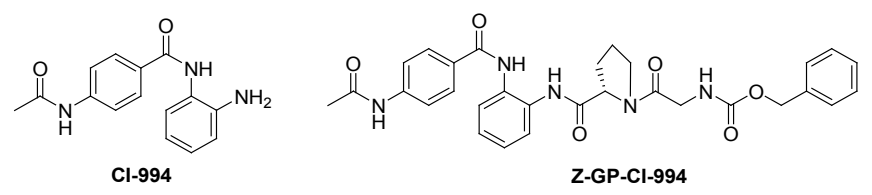

Figure 1: Chemical structures of $\mathrm{Cl}-994$ and Z-GP-Cl-994.

*Corresponding authors: Heru Chen, Institute of Traditional Chinese Medicine and Natural Products, College of Pharmacy, Jinan University, Guangzhou 510632, P. R. China, E-mail: thrchen@jnu.edu.cn

Shao-hui Cai, Department of Clinical Pharmacology, College of Pharmacy, Jinan University, Guangzhou 510632, P.R. China, E-mail: csh5689@sina.com

Received April 25, 2013; Accepted May 24, 2013; Published May 27, 2013

Citation: Deng Y, Gao P, Guo C, Wu L, Xu J, et al. (2013) Z-GP Modification to Cl994, a Histone Deacetylase Inhibitor and the Application in Targeting Carcinoma Chemotherapy. Med chem 3: 199-205. doi:10.4172/2161-0444.1000139

Copyright: ( 2013 Deng Y, et al. This is an open-access article distributed under the terms of the Creative Commons Attribution License, which permits unrestricted use, distribution, and reproduction in any medium, provided the original author and source are credited. 
purchased from GIBCO (Invitrogen, USA). All culture flasks were obtained from Corning (USA). All other chemicals used were reagent grade or higher grade and obtained from Sigma-Aldrich or Merck, and were used without further purification.

Human hepatocarcinoma cells (HepG2), human lung cancer cells (A549), murine fibroblast cells (NIH3T3) and human embryonic kidney 293 cells (HEK293) were obtained from China Center for Type Culture Collection (Shanghai, China). HEK293/FAPa ${ }^{+}$cells, 4T1/FAP $\alpha^{+}$cells and $\mathrm{NIH} 3 \mathrm{~T} 3 / \mathrm{FAP}^{+}$cells were establishment and maintained by our own laboratory.

Female C57BL/6 mice were purchased from Animal Experimental Center of Guangdong Province (Guangzhou, China). MT/ret transgenic 304/B6 male seed mice were presented by the Immunology Department of the Medicine School of Nagoya University. All animals were kept under standard pathogen-free conditions and MT/ret 304/ B6 seed mice were backcrossed twice with C57BL/6 mice. All animal studies were conducted in accordance with institutional guidelines for the care and use of experimental animals.

General procedures: NMR spectra were recorded on Bruker AV300 (Bruker Biospin, Swiss). Tetramethylsilane (TMS) was used as internal standard. ESI-MS were recorded on Finnigan LCQ Advantage MAX mass spectrometer. HPLC for preparation was performed on a LC-100 liquid chromatograph equipped with a tunable LC-100 UV detector (Shanghai Wufeng Inc., China) and HPLC for enzymatic cleavage of Z-GP-CI-994 and Z-GP-Dox was performed with Agilent 1200 series liquid chromatograph equipped with an Agilent 1200 Series UV detector (Agilent Technologies, USA). SynergyMx MultiMode Microplate Reader (Bio-Tek, USA) was used for measure the fluorescence. Pre-coated thin-layer chromatography (TLC) plates (Institute of Yantai Chemical Industry, China) were used for tracing. Spots on TLC plates were detected by either a ZF-7A portable UV detector or spraying $\mathrm{KMnO}_{4}$ solution followed sebsequent heating. $\mathrm{N}, \mathrm{N}$-dimethylformamide (DMF) was reluxed over $\mathrm{CaH}_{2}$ for $2 \mathrm{hrs}$ and redistilled under reduced pressure; Tetrahydrofuran (THF) was dried over sodium thread and then freshly distilled. Dichloromethane (DCM) was dried over $\mathrm{P}_{2} \mathrm{O}_{5}$ for 2 hrs and redistilled.

\section{Synthesis of Z-GP-CI-994}

Synthesis of 4-acetamidobenzoic acid: To a solution of acetic anhydride $45 \mathrm{ml}(0.47 \mathrm{~mol})$ was added $p$-aminobenzoic acid $6.86 \mathrm{~g}$ $(0.05 \mathrm{~mol})$. After completely mixing, the solution as allowed to warm up to $70^{\circ} \mathrm{C}$. The reaction was lasted for $4 \mathrm{hrs}$ with stirring. Then the mixture was cooled down to room temperature. Crude residues were collected by filtration and purified by crystallization in hot water resulted in 4-acetamidobenzoic acid in white solid $8.27 \mathrm{~g}(92.3 \%) .{ }^{1} \mathrm{H}$ $\operatorname{NMR}\left(300 \mathrm{MHz}, \mathrm{DMSO}-d_{\mathrm{f}}\right) \delta: 12.66(\mathrm{~s}, 1 \mathrm{H}, \mathrm{OH}), 10.23(\mathrm{~s}, 1 \mathrm{H}, \mathrm{NH})$, $7.88(\mathrm{~d}, J=8.68 \mathrm{~Hz}, 2 \mathrm{H}, \mathrm{Ar}-\mathrm{H}), 7.69(\mathrm{~d}, J=8.68 \mathrm{~Hz}, 2 \mathrm{H}, \mathrm{Ar}-\mathrm{H}), 2.07(\mathrm{~s}$, $\left.3 \mathrm{H}, \mathrm{CH}_{3}\right)$; ESI-MS $(\mathrm{m} / z)$ : calcd for $\mathrm{C}_{9} \mathrm{H}_{9} \mathrm{NO}_{3}+\mathrm{H}$ : 180.17, found: 180.21 .

Synthesis of 4-acetamido-N-(2-aminophenyl)benzamide (CI994): 4-Acetamido- benzoic acid $3.58 \mathrm{~g}(0.02 \mathrm{~mol})$ was dissolved in 20 $\mathrm{ml}$ of anhydrous THF. The solution was cooled down to $0^{\circ} \mathrm{C}$ with icebatch. Then triethylamine $5.06 \mathrm{~g}(0.05 \mathrm{~mol})$ and ethyl chloroformate $3.26 \mathrm{~g}(0.03 \mathrm{~mol})$ were added respectively. The mixed solution was warmed up to room temperature and kept stirring for $1 \mathrm{hr}$. This solution was then added drop wisely to a solution of benzene-1,2-diamine $17.3 \mathrm{~g}$ $(0.16 \mathrm{~mol})$ in $30 \mathrm{ml}$ of anhydrous THF. The mixture was stirred for 10 hrs avoid of light. Solvents were then removed by evaporation under reduced pressure. Afterwards, $100 \mathrm{ml}$ dichloromethane and $100 \mathrm{ml}$ of $6 \mathrm{M} \mathrm{HCl}$ aqueous solution were added to the residue. The organic layer was then extracted twice with $100 \mathrm{ml}$ water respectively. All the aqueous extracts were combined and $\mathrm{pH}$ value of the solution was adjusted to 7 with ammonia. All the solid compounds were collected by filtration and purified by crystallization with hot water led to CI-994 in yellowish solid $2.94 \mathrm{~g}(51.5 \%) .{ }^{1} \mathrm{H}$ NMR $\left(300 \mathrm{MHz}\right.$, DMSO- $\left.d_{6}\right) \delta: 10.26$ (s, 1H, NH), $9.56(\mathrm{~s}, 1 \mathrm{H}, \mathrm{NH}), 7.94(\mathrm{~d}, J=8.67 \mathrm{~Hz}, 2 \mathrm{H}, \mathrm{Ar}-\mathrm{H}), 7.69(\mathrm{~d}$ $J=8.67 \mathrm{~Hz}, 2 \mathrm{H}, \operatorname{Ar}-\mathrm{H}), 7.15(\mathrm{~d}, J=8.87 \mathrm{~Hz}, 1 \mathrm{H}, \operatorname{Ar}-\mathrm{H}), 6.95(\mathrm{~m}, 1 \mathrm{H}$, Ar-H), 6.77 (d, $J=8.57 \mathrm{~Hz}, 1 \mathrm{H}, \mathrm{Ar}-\mathrm{H}), 6.60$ (m, 1H, Ar-H), 4.88 (brs, $\left.2 \mathrm{H}, \mathrm{NH}_{2}\right), 2.09\left(\mathrm{~s}, 3 \mathrm{H}, \mathrm{CH}_{3}\right)$; ESI-MS $(m / z)$ : calcd for $\mathrm{C}_{15} \mathrm{H}_{15} \mathrm{~N}_{3} \mathrm{O}_{2}+\mathrm{H}$ : 270.12, found: 270.11 .

Synthesis of (S)-4-acetamido-N-(2-(N-benzyloxycarbonylglycylprolyl)aminophenyl) benzamide (Z-GP-CI-994): To a solution of $N$-benzyloxycarbonylglycylproline $147.0 \mathrm{mg}(0.48 \mathrm{mmol})$ in $3 \mathrm{ml}$ of dried DMF, triethylamine $0.08 \mathrm{ml}(0.58 \mathrm{mmol})$ and ethyl chloroformate $0.06 \mathrm{ml}(0.58 \mathrm{mmol})$ was added at $0^{\circ} \mathrm{C}$. The mixed solution was stirred for $0.5 \mathrm{hr}$ at $0^{\circ} \mathrm{C}$ and then warmed up to room temperature. Then a solution of CI-994 $107.7 \mathrm{mg}(0.4 \mathrm{mmol})$ in $2 \mathrm{ml}$ of dried DMF was added dropwisely via syringe. The mixture was stirred at r.t. for 20 hrs. Afterwards, DMF was removed by lyophilization. The residues were then submitted to RP-HPLC (Column: Cosmosil C 18 20×250 mm; $\lambda$ : $254 \mathrm{~nm}$; Eluant: $55 \%$ methanol in water) for purification led to $\mathrm{Z}$ GP-CI-994 in white solid $120.0 \mathrm{mg}$ (53.8\%). Purity: $96.2 \%$; ${ }^{1} \mathrm{H}$ NMR $\left(300 \mathrm{MHz}, \mathrm{CDCl}_{3}\right) \delta: 9.35(\mathrm{~s}, 1 \mathrm{H}), 9.24(\mathrm{~s}, 1 \mathrm{H}), 8.50(\mathrm{~s}, 1 \mathrm{H}), 7.80(\mathrm{~d}$, $J=8.6 \mathrm{~Hz}, 2 \mathrm{H}), 7.50(\mathrm{~d}, J=8.4 \mathrm{~Hz}, 2 \mathrm{H}), 7.44(\mathrm{~m}, 2 \mathrm{H}), 7.27(\mathrm{~m}, 3 \mathrm{H})$ $7.21(\mathrm{~m}, 2 \mathrm{H}), 7.09(\mathrm{~m}, 2 \mathrm{H}), 5.33(\mathrm{t}, J=4.4 \mathrm{~Hz}, 1 \mathrm{H}), 4.90(\mathrm{~m}, 2 \mathrm{H}), 4.40$ (m, 1H), $3.77(\mathrm{~m}, 2 \mathrm{H}), 3.32(\mathrm{~m}, 2 \mathrm{H}), 2.04(\mathrm{~m}, 3 \mathrm{H}), 1.95(\mathrm{~s}, 3 \mathrm{H}), 1.88$ $(\mathrm{m}, 1 \mathrm{H}) ;{ }^{13} \mathrm{C}$ NMR $\left(75 \mathrm{MHz}, \mathrm{CDCl}_{3}\right) \delta: 170.8,169.3,168.5,166.3,156.4$ $141.8,136.3,130.6,130.0,128.7,128.6,128.4,128.0,127.6,126.2,126.0$, $125.5,125.3,119.2,66.6,61.1,46.4,43.3,29.2,24.5,24.3$; ESI-MS $(m / z)$ : calcd for $\mathrm{C}_{30} \mathrm{H}_{31} \mathrm{~N}_{5} \mathrm{O}_{6}+\mathrm{H}$ : 558.22 , found: 558.3 ; HRMS $(\mathrm{m} / z)$ : calcd for $\mathrm{C}_{30} \mathrm{H}_{31} \mathrm{~N}_{5} \mathrm{O}_{6}+\mathrm{Na}: 580.21665$, found: 580.21699 .

\section{Methods and assays}

Stability investigation: Z-GP-CI-994 was incubated in $0.01 \mathrm{~mol} / \mathrm{L}$ phosphate buffer ( $\mathrm{pH}$ 7.4) solution, RPMI 1640 culture medium and Dulbecco's modified Eagle's medium (DMEM) with $10 \%$ fetal bovine serum at $37^{\circ} \mathrm{C}$ for $72 \mathrm{hrs}$ respectively. Reverse-phase high performance liquid chromatography (RP-HPLC) was performed on a Cosmosil column $\left(\mathrm{C}_{18}, 5 \AA\right.$, $\left.4.6 \times 250 \mathrm{~mm}\right)$ using Agilent 1200 series HPLC system to monitor the changing of Z-GP-CI-994 at each sheduled time points. The eluent used was $55 \%$ methanol containing pure water (flow rate: $1.0 \mathrm{ml} / \mathrm{min} ; \lambda: 254 \mathrm{~nm}$ ). The experiments were repeated at least 3 times and compared with the control experiment.

Cell culture: HepG2, A549 and 4T1/FAP ${ }^{+}$were cultured in RPMI 1640 culture medium and HEK293, HEK293/FAPa ${ }^{+}$, NIH3T3, $\mathrm{NIH} 3 \mathrm{~T} 3 / \mathrm{FAPa}^{+}$were maintained in Dulbecco's modified Eagle's medium (DMEM) culture medium at $37^{\circ} \mathrm{C}$ with $5 \% \mathrm{CO}_{2}$. All growth media used were supplemented with $10 \%$ fetal bovine serum, $100 \mathrm{U} / \mathrm{mL}$ penicillin and $100 \mathrm{U} / \mathrm{mL}$ streptomycin. Culture medium was routinely changed every 2 days. For subculture, cells were released from the flasks by treatment with $0.25 \%$ trypsin/EDTA. For experiments, cells at the logarithmic grow phase were used.

Measurement of cytotoxicity in vitro: Cell viability were estimated using methyl thiazolyl tetrazolium (MTT) (sigma, USA) assay. HepG2, A549, NIH3T3 and HEK293 was seeded in a 96-well plate respectively at a cell density of 4,000 cells per well. After overnight growth, Z-GP-CI-994 and CI-994 were added to the culture media at various concentrations $(0.01 \sim 30 \mu \mathrm{M})$ for $48 \mathrm{hrs}$ and $72 \mathrm{hrs}$ respectively. Cytotoxicity was assayed by 3-(4,5-dimethyl-2-thiozolyl)-2,5-diphenyl tetrazolium bromide (MTT) dye uptake. The cells were incubated at $37^{\circ} \mathrm{C}$ for $4 \mathrm{~h}$ with MTT at $10 \%$ of culture volume. After incubation 
period, cultures were removed from incubator and the resulted formazan was dissolved in $150 \mu \mathrm{L}$ of dimethyl sulphoxide (DMSO). Then, the plates were gently shaken to solubilize the formed formazan. The absorbance was measured at $490 \mathrm{~nm}$ using an ELISA reader (BioRad Laboratories Inc., USA). The effect of Z-GP-CI-994 or CI-994 on growth inhibition was assessed as percent cell viability where DMSOtreated cells were taken as $100 \%$ viability. The concentrations of DMSO used at all the experiments were guaranteed no discernable effect on cells viability.

HDAC activity assay: The experiments were carried out following the direct assay kit by manufacturer's procedures of Epigenase HDAC activity/inhibition. Z-GP-CI-994 and CI-994 at various concentrations $(1.0 \sim 5.0 \mu \mathrm{M})$ was incubated with HDAC standard solution and substrate. After antibody binding and signal enhancing, the fluorescence was read at $530_{\mathrm{Ex}} / 590_{\mathrm{EM}} \mathrm{nm}$ within 2 to $10 \mathrm{~min}$ on the fluorescence microplate reader. HDAC inhibition percentage was calculated using the following formulas:

Inhibition $\%=\left[1-\frac{\text { Inhibitor Sample RFU - Blank RFU }}{\text { No Inhibitor Sample RFU - Blank RFU }}\right] \times 100 \%$

Enzymatic hydrolysis: HEK293/FAPa ${ }^{+}$cells, 4T1/FAPa ${ }^{+}$cells, $\mathrm{NIH} 3 \mathrm{~T} 3 / \mathrm{FAPa}^{+}$cells, and corresponding $\mathrm{FAPa}-$ cells were seeded in a 12 -well plate at a cell density of $2 \sim 3 \times 10^{5}$ cells per well respectively. After overnight growth, culture medium was changed to fresh medium contained the prodrug Z-GP-CI-994 $(30 \mu \mathrm{M})$ and incubated for scheduled time. The culture media without cells incubated with the compound was set as control. In the mean time, Z-GP-CI-994 was incubated with $0.25 \%$ trypsin/EDTA or culture medium without cells in order to exclude non-specific hydrolysis. Then each culture supernatants was collected and transferred to tubes containing $5 \mathrm{~mL}$ of methylene dichloride and acetonitrile $(4: 1, \mathrm{~V} / \mathrm{V})$ and $500 \mu \mathrm{L}$ methanol respectively. The tubes were shaken vigorously, and the organic layers were collected by centrifugation respectively. After solvent evaporation, the residues in each tubes were dissolved in $100 \mu \mathrm{L}$ of methanol respectively. All the samples were filtered $(0.22 \mu \mathrm{m})$ and analyzed by HPLC to evaluate the enzymolytic efficiency of Z-GP- CI-994.

Z-GP-CI-994 was incubated in Tris-buffer (pH 7.4) with rhFAPa $(2 \mu \mathrm{g} / \mathrm{mL})$ at a final concentration of $50 \mu \mathrm{M}$ at $37^{\circ} \mathrm{C}$. Simultaneously, $\mathrm{Z}$-GP-Dox was incubated in the same way as a comparison. The samples at each scheduled time points were collected and analyzed by HPLC method.

HPLC for cleavage of Z-GP-CI-994 was performed in Agilent 1200 series (USA). The profile: UV-detection at $254 \mathrm{~nm}$; Column: Cosmosil $\mathrm{C}_{18}(5 \AA, 4.6 \times 250 \mathrm{~mm})$ with precolumn; flow rate: $1.0 \mathrm{~mL} /$ min; eluant: $55 \%$ methanol in water (isocratic elution); injection: 20 $\mu \mathrm{L}$. HPLC profile for the cleavage of Z-GP-Dox was as following: UVdetection at $495 \mathrm{~nm}$; flow rate: $1.0 \mathrm{~mL} / \mathrm{min}$; eluant: methanol $/ 0.1 \mathrm{vol} \%$ trifluoroacetic acid in water, program: 30\%-60\% methanol within 40 min (gradient); injection: $20 \mu \mathrm{L}$.

Targeted delivery: The newborn MT/ret 304/B6 transgenic mice (with all-black skin at 5 days after birth) were raised to 8 -weeks age with whole-body palpable tumors in this study; tumor tissues were obtained from the tumor-bearing mice. Subsequently, tumor tissues were cut into small fragments. $200 \mathrm{mg}$ of fragments were added to 800 $\mu \mathrm{l}$ buffer [50 mM Tris- $\mathrm{HCl}$ buffer ( $\mathrm{pH}$ 7.4)] to prepare homogenates. Z-GP-CI-994 was added into homogenates at a final concentration of $30 \mu \mathrm{M}$ and incubated at $37^{\circ} \mathrm{C}$ for $24 \mathrm{hrs}$. The samples were collected at scheduled time points and processed respectively. Then RP-HPLC analyses were carried on applied the above assay.
Statistics: All results are reported as means \pm SEM over 3-5 experiments. Differences between groups were analyzed using ANOVA, followed by Dunnett's multi-comparison test with PASW Software (SPSS Inc., Chicago, IL, USA). P-value less than 0.05 were considered statistically significant.

\section{Results and Discussions}

\section{Chemistry and stability}

Chemistry: The synthesis of Z-GP-CI-994, which was named (S)4-acetamido- $N$-(2-(N-benzyloxycarbonylglycylprolyl)aminophenyl) benzamide is outlined in Scheme 1. First, $p$-aminobenzoic acid was turned into 4-acetamidobenzoic acid at $70^{\circ} \mathrm{C}$ using acetic anhydride, which played dual roles as reagent and solvent. The yield was $92.3 \%$. Afterwards, 4-acetamidobenzoic acid reacted with benzen-1,2- diamine applied ethyl chloroformate as coupling reagent. In order to avoid the formation of diacetylation of benzen-1,2-diamine, the activated intermediate of 4-acetamidobenzoic acid should be added dropwisely to the solution of excess benzen-1,2-diamine. After work up, CI-994 was obtained in mild yield, which was $51.5 \%$. At last, coupling of CI994 with $\mathrm{N}$-benzyloxycarbonylglycylproline (Z-GP-OH) led to the final product, that is, the Z-GP-CI-994. The yield was moderate, which was $53.8 \%$.

Stability: The stability of Z-GP-CI-994 was evaluated by incubating this compound in either $0.01 \mathrm{~mol} / \mathrm{L}$ phosphate buffer $(\mathrm{pH} 7.4)$ or cell culture media supplemented with $10 \%$ fetal bovine serum at $37^{\circ} \mathrm{C}$. The evolution of each solutions was analysed by HPLC with UV detection over a period of $72 \mathrm{hrs}$. As expected, Z-GP-CI-994 is quite stable in the course of these experiments, no detectable decomposition was observed in PBS buffer medium; while only less than $0.1 \%$ and $1 \%$ cleavage of the adduct were observed in PRMI 1640 and DMEM culture media respectively (Figure 2).

\section{Interaction of Z-GP-CI-994 with cells and enzymes}

Anti-proliferative activity: To validate the assumption that the cytotoxicity of CI-994 might be reduced through the modification of Z-GP. The cytotoxicity of both CI-994 and Z-GP-CI-994 against HepG2, A549 and NIH3T3 using MTT assay were assessed respectively. As depicted in Figure 3, Z-GP-CI-994 exhibited extremely low cytotoxicity against HepG2, A549 and NIH3T3cells. After 48-hours treatment, the prodrug did not exhibit any anti-proliferative activity on HepG2 cells; whereas CI-994 displayed potent cytotoxicity against HepG2 cells with $\mathrm{IC}_{50}$ value of $14 \mu \mathrm{M}$. There was a similar decreased cytotoxicity against A549 cells. It was found that even at a concentration up to $30 \mu \mathrm{M}$, the prodrug killed only about $29 \%$ of the cells, however CI-994 at the same concentration killed about $73 \%$ of the cells.

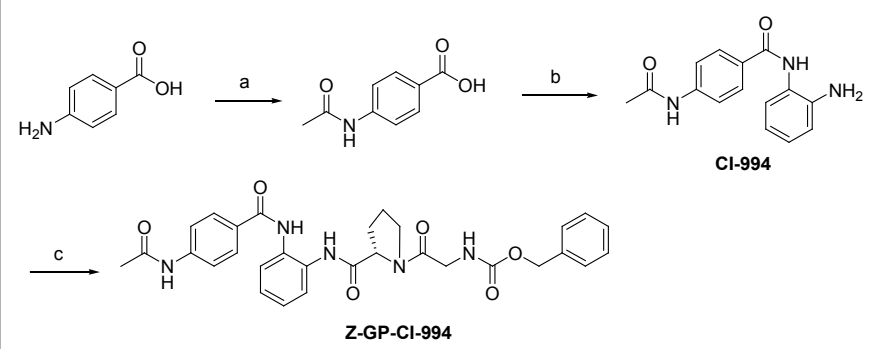

Scheme 1: Synthesis of Z-GP-Cl-994. Reagents and conditions: (a) $\left(\mathrm{CH}_{3} \mathrm{CO}\right)_{2} \mathrm{O}, 70^{\circ} \mathrm{C}, 4 \mathrm{hr}, 92.3 \%$; (b) $\mathrm{Et}_{3} \mathrm{~N} / \mathrm{ClCOOEt}$, benzene-1,2-diamine, rt, 10 hr, 51.5\%; (c) Et ${ }_{3} \mathrm{~N} / \mathrm{CICOOEt}$, Z-GP-OH, rt, 20 hr, 53.8\%. 
Additionally, the cytotoxicity of Z-GP-CI-994 on normal cells is likewise necessary to determined. The murine fibroblast cells NIH3T3

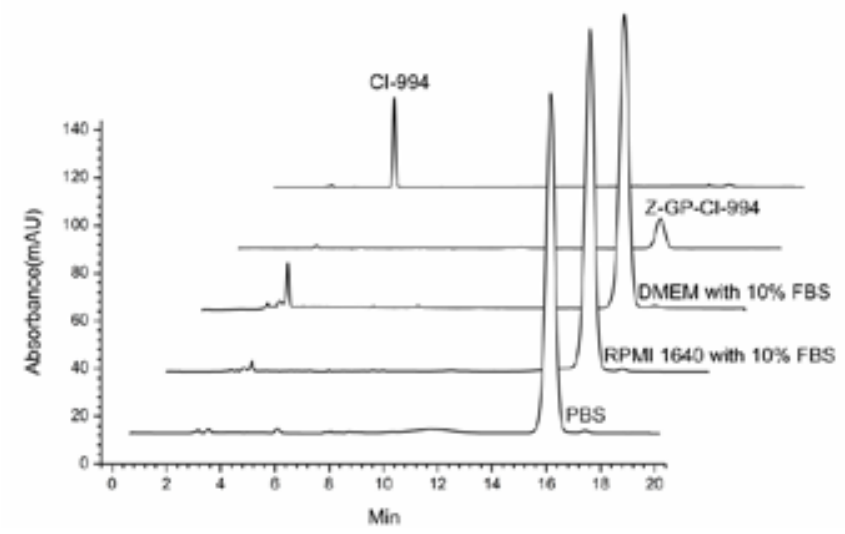

Figure 2: The stability of Z-GP-Cl-994 in either PBS or culture medium with $10 \%$ fetal bovine serum at $37^{\circ} \mathrm{C}$ for $72 \mathrm{~h}$. Concentration of Z-GP-Cl-994: 30 $\mu \mathrm{M}$.

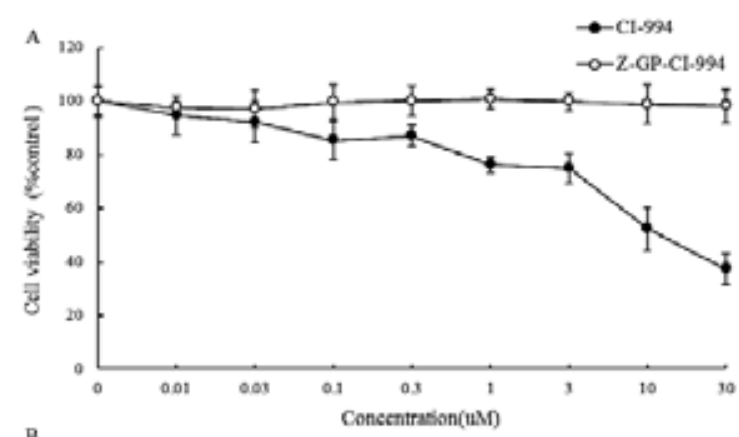

B
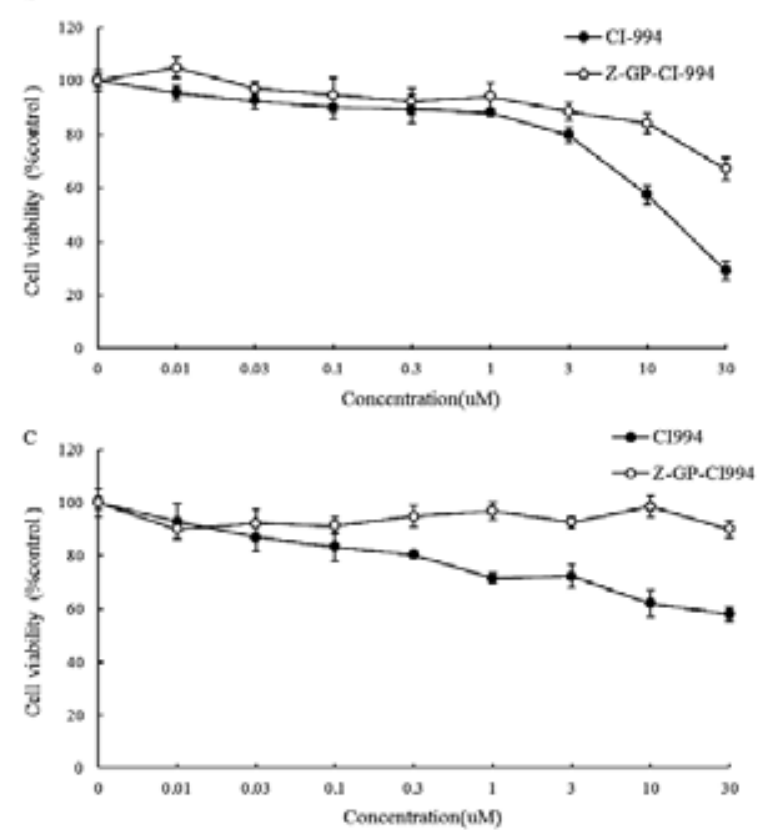

Figure 3: Anti-proliferative activity of HepG2 cells (A), A549 cells (B) and NIH3T3 cells (C) treated $48 \mathrm{hrs}$ with Cl-994 and Z-GP-Cl-994 respectively. Experiments were done in triplicate. Standard deviation is indicated.

\begin{tabular}{|l|l|l|}
\hline $\begin{array}{l}\text { Group } \\
\text { Conc. }(\mu \mathrm{M})\end{array}$ & \multicolumn{2}{|l|}{ Inhibition rate $(\%)$ on $\mathrm{HDAC}(\bar{x} \pm S D, \mathrm{n}=3)$} \\
\hline 1.0 & $\mathrm{Cl}-994$ & Z-GP-Cl-994 \\
\hline 2.0 & $48.72 \pm 3.79$ & $14.02 \pm 2.26^{*}$ \\
\hline 3.0 & $56.65 \pm 5.63$ & $28.97 \pm 6.34^{*}$ \\
\hline 4.0 & $61.44 \pm 1.09$ & $22.55 \pm 9.66^{*}$ \\
\hline 5.0 & $68.53 \pm 2.74$ & $31.13 \pm 4.46^{*}$ \\
\hline
\end{tabular}

t-test vs $\mathrm{Cl}-994:{ }^{*} \mathrm{P}<0.01$

Table 1: The inhibitory effects of Cl-994 and Z-GP-Cl-994 on HDAC.

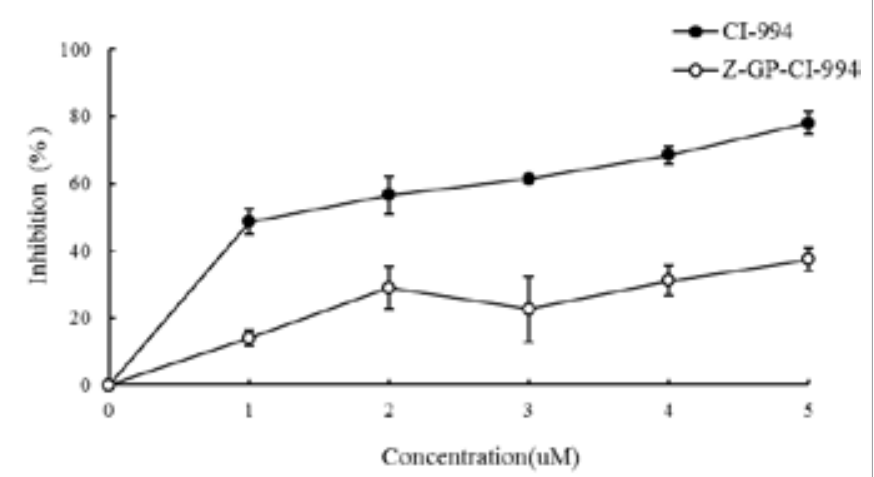

Figure 4: The inhibitory effects of $\mathrm{Cl}-994$ and Z-GP-Cl-994 on HDAC ( $\bar{x} \pm$ $S D . \mathrm{n}=3)$.

was used as representative normal cell in the current study. As shown in Figure 3C, when the concentration of Z-GP-CI-994 comes to 30 $\mu \mathrm{M}$, the cell viability was still higher than $90 \%$; while in the case of CI994 , the cell viability was only $58 \%$. This evidence demonstrated that modification with Z-GP does decrease the cytotoxicity of CI-994.

HDAC activity assay: It is well known that CI-994 is a potent member of the benzamide class of HDAC inhibitors. Therefore, whether the Z-GP modification blocks the active site of CI-994 is a key problem needed to make clear. The inhibition rates of Z-GP-CI-994 and CI-994 on HDAC were measure at the current investigation. As illustrated in Table 1 and Figure 4, the inhibitory effect of Z-GP-CI-994 on HDAC was significantly lower when compared to that of CI-994 at the same concentration. When Z-GP-CI-994 was at a high concentration up to $5 \mu \mathrm{M}$, the inhibition rate on HDAC was only $37.43 \% \pm 3.52 \%$; whereas CI-994 at the same concentration showed $78.04 \%$ inhibition rate. This evidence supports that Z-GP modification does block the active site of CI-994 to a great extent.

Enzymatic hydrolysis: Enzymatic hydrolysis of the prodrug was first conducted in the FAPa-positive cell lines. In order to identify the specificity of FAPa, corresponding non-FAPa-positive cell lines were concomitantly tested. As shown in Figure 5A to 5C, after incubating with HEK293 and HEK293/FAPa ${ }^{+}$cells, 4T1 and 4T1/FAP $\alpha^{+}$cells, NIH3T3 and NIH3T3/FAPa ${ }^{+}$cells, unexpectively, it was found that Z-GP-CI-994 could be cleaved effectively by both FAPa-positive and FAP $\alpha$-negative cell lines. More surprisingly, the hydrolytic rates of both FAP $\alpha$ positive and negative cell lines displayed no significant difference. These evidences implied that Z-GP-CI-994 was cleaved by another enzyme but not FAP $\alpha$.

To confirm further whether Z-GP-CI-994 could be cleaved by FAPa or not, a separated experiment of enzymatic hydrolysis was carried out. $50 \mu \mathrm{M}$ of the conjugates were incubated with $\operatorname{rhFAP} \alpha(2 \mu \mathrm{g} / \mathrm{mL})$ 

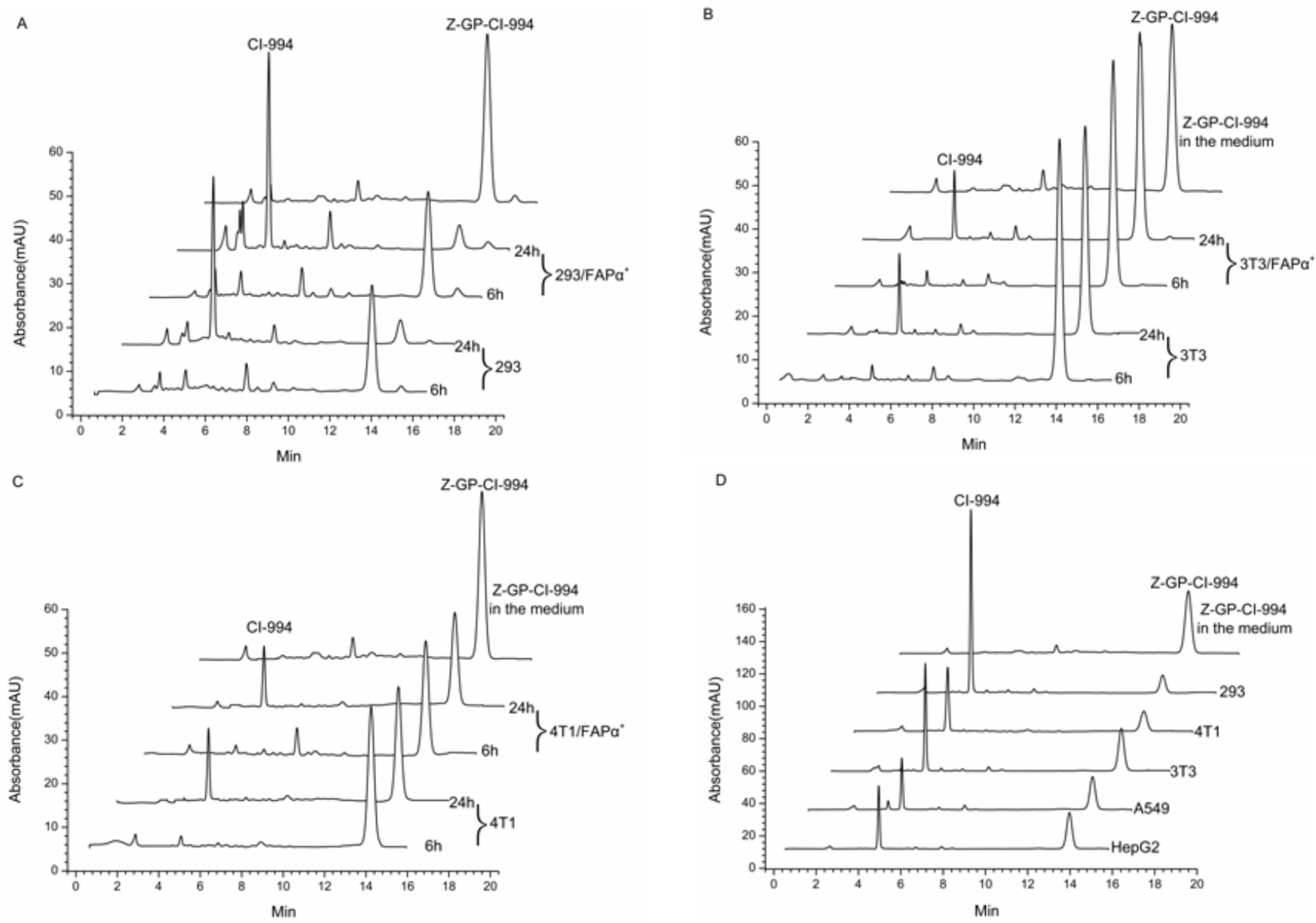

Figure 5: Cleavage of Z-GP-Cl-994 when incubating with (A) HEK293 and HEK293/FAPa ${ }^{+}$cells; (B) 3 T3 and 3T3/FAPa ${ }^{+}$cells; (C) 4T1 and 4T1/FAPa ${ }^{+}$cells; (D)

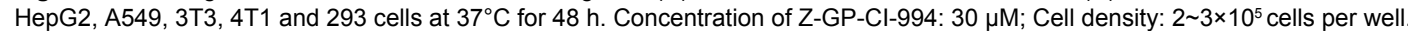

at $37^{\circ} \mathrm{C}$. As shown in Figure 6A, Z-GP-CI-994 kept intact during the course of incubation. Obviously, rhFAPa is not able to cleave Z-GPCI-994 to CI-994. However, as a comparison, Z-GP-Dox(16) could be effectively cleaved by FAPa (Figure 6B), which confirmed that the enzyme work properly. From the view point of chemical structure, doxorubicin is more complex than CI-994. Therefore the reason why the Z-GP adduct of CI-994 cannot be hydrolyzed by FAPa shall not be ascribed to steric hindrance caused by molecular complexity [24]. This evidence discloses that FAPa is not able to hydrolyze any Z-GP adducts universally.

Targeting characteristics of Z-GP-CI-994 in tumor homogenate: One of the most critical purposes to design antitumor prodrugs is to improve the targeting effect of cytotoxic agents and thereby to reduce their systemic side effects. It is imperative to investigate whether the conjugate could be effectually hydrolyzed in the tumor tissue. In the current study, tumor homogenate of MT/ret 304/B6 mice with wholebody palpable tumors was used for this purpose. As illustrated in Figure 7A, Z-GP-CI-994 (30 $\mu \mathrm{M})$ was cleaved to CI-994 completely, in the mean time it resulted in another unknown metabolite which presented a peak at $2.9 \mathrm{~min}$ after $0.5 \mathrm{~h}$ of incubation with tumor homogenate. With the procedure going on, peak area of CI-994 decreased gradually while the area of peak at 2.9 min increased concomitantly.

As a comparison, CI-994 was incubated with the same kind of tumor homogenate. It was found that the peak area of CI-994 gradually dwindled and completely disappeared after 24-hours incubation; while a new distinct peak was observed at $2.9 \mathrm{~min}$ and rose along with the falling of CI-994 peak (Figure 7B). These evidences substantiated that Z-GP-CI-994 is rapidly cleaved by tumor tissue and has a similar metabolic behavior to CI-994 in tumor tissue. In other word, Z-GPCI-994 is hydrolyzed by other unknown enzyme which is ubiquitous in tumor tissue apart FAPa to release CI-994 and plays the similar role as CI-994.

\section{Conclusions}

In summary, a novel concise synthesis of Z-GP-CI-994 has been successfully developed. Although the purpose of Z-GP modification to CI-994 had been targeted to FAPa, the evidence discloses that Z-GPCI-994 is not the substrate of FAPa. This is the first Z-GP adduct reported that cannot be cleaved by FAPa. Interestingly, Z-GP-CI-994 can be hydrolyzed by another unknown enzyme which is ubiquitous in tumor tissue. The cytotoxicity of Z-GP-CI-994 against either tumor cell lines including HepG2 cells and A549 cells or normal cell lines NIH3T3 cells is apparently decreased when compared to that of CI-994. The inhibition rate to HDAC is lowered down when CI-994 is modified with Z-GP. All the evidences come to support that Z-GP-CI-994 is promising to achieve targeted delivery as well as to reduce the side effects of CI-994. However, the comprehensive action mechanism of Z-GP-CI-994 needs to be further investigated. 
Citation: Deng Y, Gao P, Guo C, Wu L, Xu J, et al. (2013) Z-GP Modification to Cl-994, a Histone Deacetylase Inhibitor and the Application in Targeting Carcinoma Chemotherapy. Med chem 3: 199-205. doi:10.4172/2161-0444.1000139

A

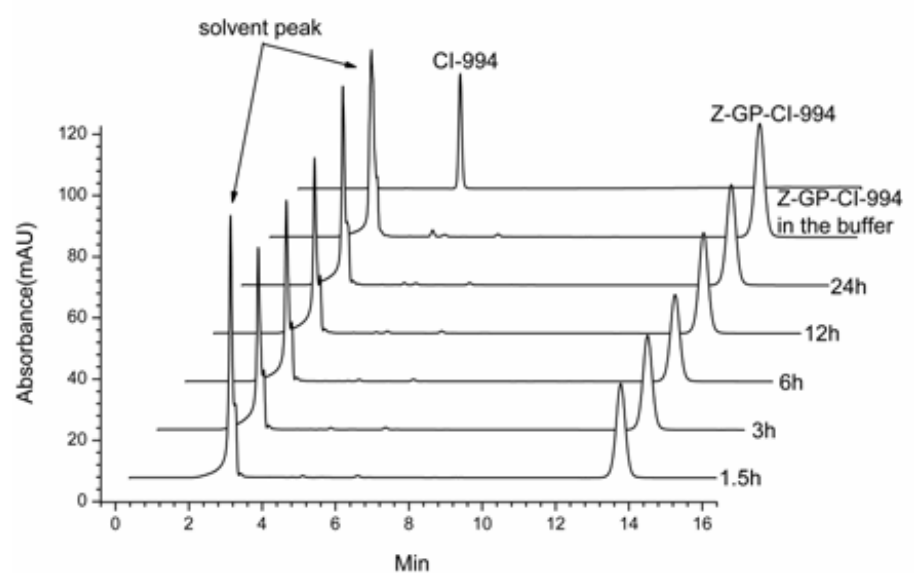

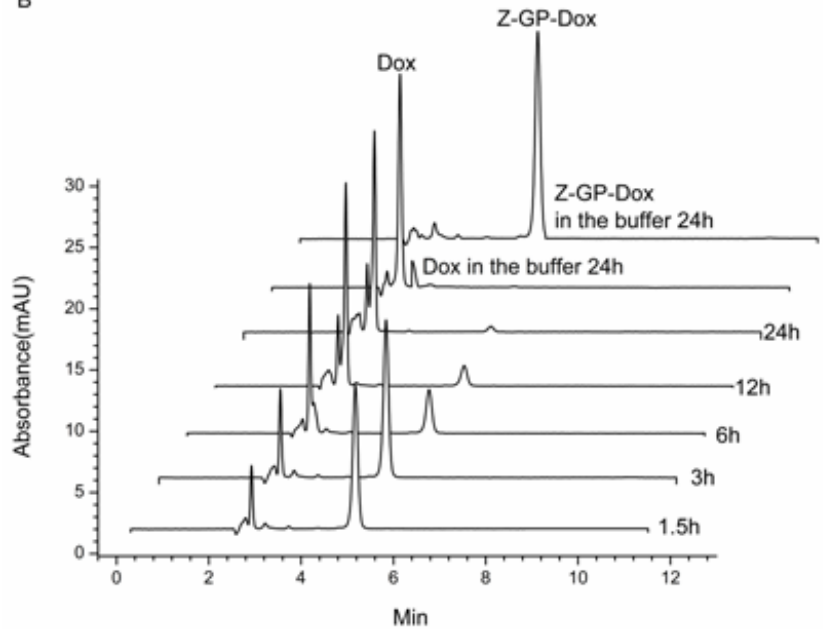

Figure 6: Enzymatic cleavage of Z-GP-Cl-994 (A) and Z-GP-Dox (B). Prodrug concentretion: $50 \mu \mathrm{M}$; Enzyme concentration: $2 \mu \mathrm{g} / \mathrm{mL}$.

A

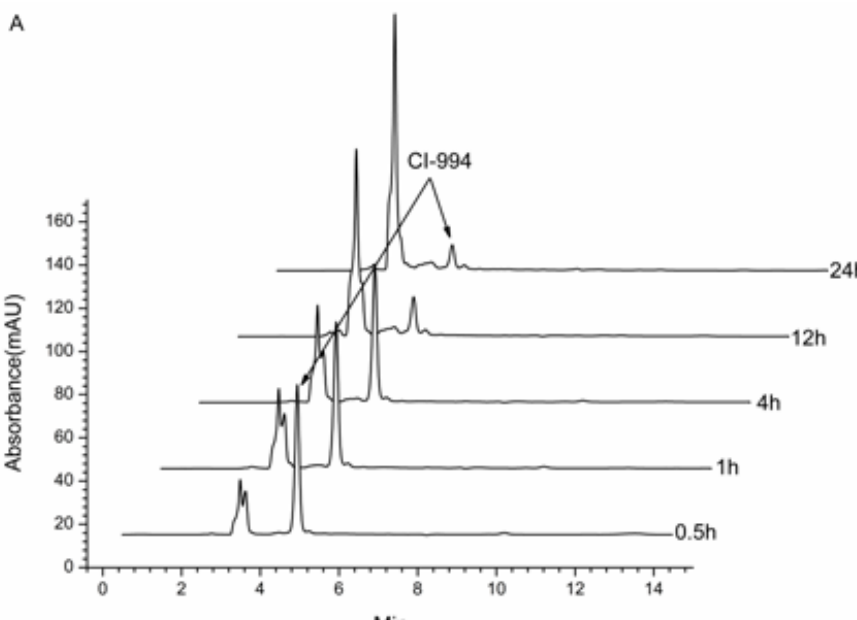

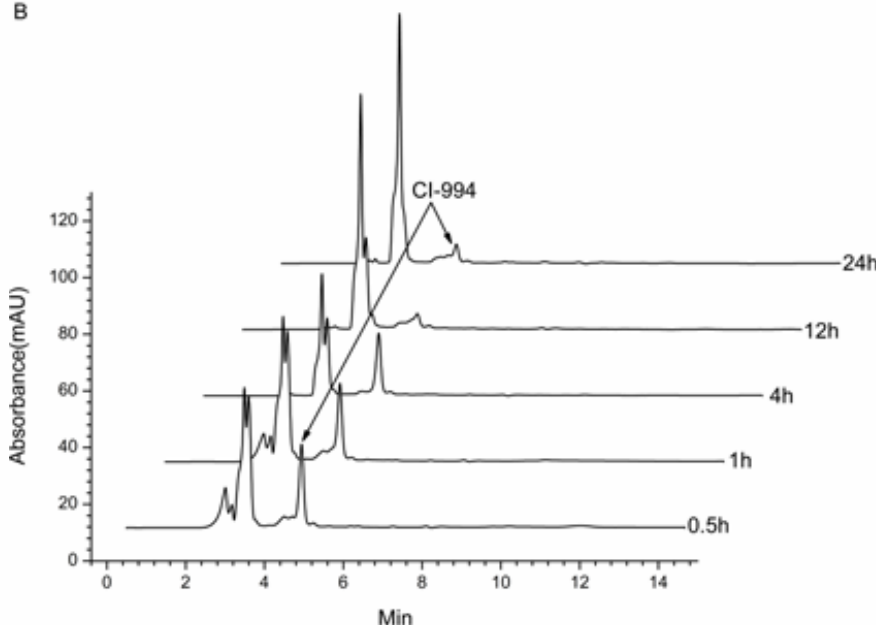

Figure 7: Chromatograms of incubation studies of Z-GP-Cl-994 (A) and Cl-994 (B) with mouse tumor homogenate at $37^{\circ} \mathrm{C}$ for $24 \mathrm{~h}$. The concentration of compounds was $30 \mu \mathrm{M}$.

\section{Acknowledgements}

This research was financially supported by National Natural Science Foundation of China (Nos. 81172982 and 30973565) and the Guangdong Provincial Project of Science and Technology (No. 2010A030100006).

\section{References}

1. Ruefli AA, Bernhard D, Tainton KM, Kofler R, Smyth MJ, et al. (2002) Suberoylanilide hydroxamic acid (SAHA) overcomes multidrug resistance and induces cell death in P-glycoprotein-expressing cells. Int J Cancer 99: 292-298.

2. Chen $Y$, Hu L (2009) Design of anticancer prodrugs for reductive activation. Med Res Rev 29: 29-64.

3. Atkinson JM, Siller CS, Gill JH (2008) Tumour endoproteases: the cutting edge of cancer drug delivery? Br J Pharmacol 153: 1344-1352.

4. Law B, Tung $\mathrm{CH}$ (2009) Proteolysis: a biological process adapted in drug delivery, therapy, and imaging. Bioconjug Chem 20: 1683-1695.

5. Denny WA (2001) Prodrug strategies in cancer therapy. Eur J Med Chem 36: 577-595.

6. Papot S, Tranoy I, Tillequin F, Florent JC, Gesson JP (2002) Design of selectively activated anticancer prodrugs: elimination and cyclization strategies. Curr Med Chem Anticancer Agents 2: 155-185.
7. Tanabe K, Zhang Z, Ito T, Hatta H, Nishimoto S (2007) Current molecular design of intelligent drugs and imaging probes targeting tumor-specific microenvironments. Organic \& biomolecular chemistry 5: 3745-3757.

8. Rettig WJ, Garin-Chesa P, Beresford HR, Oettgen HF, Melamed MR, et al (1988) Cell-surface glycoproteins of human sarcomas: differential expression in normal and malignant tissues and cultured cells. Proc Natl Acad Sci U S A 85: 3110-3114.

9. Garin-Chesa P, Old LJ, Rettig WJ (1990) Cell surface glycoprotein of reactive stromal fibroblasts as a potential antibody target in human epithelial cancers. Proc Natl Acad Sci U S A 87: 7235-7239.

10. Scanlan MJ, Raj BK, Calvo B, Garin-Chesa P, Sanz-Moncasi MP, et al. (1994) Molecular cloning of fibroblast activation protein alpha, a member of the serine protease family selectively expressed in stromal fibroblasts of epithelial cancers. Proc Natl Acad Sci U S A 91: 5657-5661.

11. Rettig WJ, Garin-Chesa P, Healey JH, Su SL, Ozer HL, et al. (1993) Regulation and heteromeric structure of the fibroblast activation protein in normal and transformed cells of mesenchymal and neuroectodermal origin. Cancer Res 53: 3327-3335.

12. Ariga N, Sato E, Ohuchi N, Nagura H, Ohtani H (2001) Stromal expression of fibroblast activation protein/seprase, a cell membrane serine proteinase and 
Citation: Deng Y, Gao P, Guo C, Wu L, Xu J, et al. (2013) Z-GP Modification to Cl-994, a Histone Deacetylase Inhibitor and the Application in Targeting Carcinoma Chemotherapy. Med chem 3: 199-205. doi:10.4172/2161-0444.1000139

gelatinase, is associated with longer survival in patients with invasive ductal carcinoma of breast. Int J Cancer 95: 67-72.

13. Chen WT, Kelly T (2003) Seprase complexes in cellular invasiveness. Cancer Metastasis Rev 22: 259-269.

14. Collins PJ, McMahon G, O'Brien P, O'Connor B (2004) Purification, identification and characterisation of seprase from bovine serum. Int J Biochem Cell Biol 36: 2320-2333.

15. Aertgeerts K, Levin I, Shi L, Snell GP, Jennings A, et al. (2005) Structural and kinetic analysis of the substrate specificity of human fibroblast activation protein alpha. J Biol Chem 280: 19441-19444.

16. Huang S, Fang R, Xu J, Qu S, Zhang H, et al. (2011) Evaluation of the tumor targeting of a FAPİt-based doxorubicin prodrug. J Drug Target 19: 487-496.

17. el-Beltagi HM, Martens AC, Lelieveld P, Haroun EA, Hagenbeek A (1993) Acetyldinaline: a new oral cytostatic drug with impressive differential activity against leukemic cells and normal stem cells--preclinical studies in a relevant rat model for human acute myelocytic leukemia. Cancer research 53: 30083014.

18. LoRusso PM, Demchik L, Foster B, Knight J, Bissery MC, et al. (1996) Preclinical antitumor activity of Cl-994. Invest New Drugs 14: 349-356.
19. Seelig MH, Berger MR (1996) Efficacy of dinaline and its methyl and acety derivatives against colorectal cancer in vivo and in vitro. Eur J Cancer 32A: 1968-1976.

20. Pauer LR, Olivares J, Cunningham C, Williams A, Grove W, et al. (2004) Phase I study of oral $\mathrm{Cl}-994$ in combination with carboplatin and paclitaxel in the treatment of patients with advanced solid tumors. Cancer Invest 22: 886-896.

21. Undevia SD, Kindler HL, Janisch L, Olson SC, Schilsky RL, et al. (2004) A phase I study of the oral combination of $\mathrm{Cl}-994$, a putative histone deacetylase inhibitor, and capecitabine. Ann Oncol 15: 1705-1711.

22. Nemunaitis JJ, Orr D, Eager R, Cunningham CC, Williams A, et al. (2003) Phase I study of oral $\mathrm{Cl}-994$ in combination with gemcitabine in treatment of patients with advanced cancer. Cancer J 9: 58-66.

23. Thomas M, Clarhaut J, Tranoy-Opalinski I, Gesson JP, Roche J, et al. (2008) Synthesis and biological evaluation of glucuronide prodrugs of the histone deacetylase inhibitor $\mathrm{Cl}-994$ for application in selective cancer chemotherapy Bioorg Med Chem 16: 8109-8116.

24. Law B, Tung CH (2009) Proteolysis: a biological process adapted in drug delivery, therapy, and imaging. Bioconjug Chem 20: 1683-1695. 